\title{
Pemberian Ekstrak Biji Alpukat (Persea americana Mill.) dan Biji Sirsak (Annona muricata L.) terhadap Mortalitas Larva Nyamuk Culex Sp
}

\author{
S. Nombe ${ }^{1}$ dan D.K. Binawati ${ }^{2}$ \\ 1) Mahasiswa, Program Studi Biologi F.MIPA Universitas PGRI Adi Buana Surabaya \\ 2) Staf Pengajar, Program Studi Biologi F.MIPA Universitas PGRI Adi Buana Surabaya
}

\begin{abstract}
Vegetable insecticide is a natural material that is environmentally friendly. This material can be used in the prevention and control of mosquito larvae, especially Culex $s p$. Culex $s p$ is the main vector of filariasis disease and dengue hemorrhagic fever (DHF). Use of natural materials is very good and environment friendly as insectcide compared with chemicals. Avocado seed extract (Persea americana Mill) is known to have secondary metabolite content of alkaloids, saponins, triterpenoids while soursop extract (Annona muricata L) in the form of acetogenin, squamocin and annonacin. This research needs to use of avocado seed extract ( $P$. americana Mill) and soursop seed extract $(A$. muricata $\mathrm{L})$ as larvacide of Culex sp. The aim of this research is to know the effect of avocado seed extract $(P$. americana Mill) and soursop seed extract (A. muricata L) to mortality of Culex sp Instar III mosquito larvae and LC50 for 24 hours. This study was an experimental study using a complete randomized design (RAL) with five treatment concentrations $(0,2,4,6$, and $8 \%$ ) avocado seed extract ( $P$. americana Mill) and soursop extracts extract (A. muricata L) as much as five repetitions. The data obtained were analyzed by using One Way ANOVA to show the effect on the treatment. The results showed that giving of avocado seed extract $(P$. americana Mill) with $8 \%$ concentration $(23,8 \pm 0,45$ larvae) was optimal in killing Culex $s p$ mosquito larvae. While giving soursop seed extract (A. muricata L) with $4 \%$ concentration $(25 \pm 0,0$ larva) optimal in killing Culex $s p$ mosquito larvae. Avocado seed extract $(P$. americana Mill) has an effect as a larvacide against Culex sp. instar III with $\mathrm{LC}_{50}$ at concentration $2,486 \%$ while soursop extract (A. muricata $\mathrm{L}$ ) with $\mathrm{LC}_{50}$ value at concentration $1,605 \%$.
\end{abstract}

Keywords: Larvacide, soursop seed extract, avocado seed extract, Culex $s p$

\section{PENDAHULUAN}

Indonesia merupakan salah satu negara tropis di dunia yang memiliki kelembaban suhu optimal yang mendukung bagi kelangsungan hidup serangga. Serangga mempunyai peranan penting sebagai vektor (perantara) dari berbagai penyakit. Nyamuk merupakan salah satu jenis serangga yang dapat merugikan kesehatan manusia karena peranannya sebagai vektor penyakit. Beberapa jenis penyakit yang disebabkan oleh nyamuk, seperti filariasis yang ditularkan melalui nyamuk Culex sp, serta penyakit demam berdarah dengue (DBD) yang ditularkan melalui nyamuk Aedes sp. (Hariani, 2014). 
Filariasis (penyakit kaki gajah) merupakam salah satu di antara penyakit menular yang masih menjadi masalah kesehatan masyarakat Indonesia. Penyakit ini disebabkan oleh infeksi cacing filarial yang ditularkan oleh nyamuk Culex sp, yang tersebar hampir di semua pulau di Indonesia terutama di pedesaan dan pemukiman transmigrasi. Selain dapat menimbulkan demam dan rasa kelelahan, penyakit ini juga menyebabkan kecacatan tubuh yang permanen sehingga penderita tidak dapat bekerja dan akan menjadi beban bagi keluarga dan masyarakat (Pahlevi, 2013). Di kawasan Asia Tenggara termasuk Indonesia, genus Mansonia berperan sebagai vektor utama penularan filariasis dari spesies Brugia malayi. Hingga tahun 2006 telah dikonfirmasi 23 spesies nyamuk dari genus Mansonia, Anopheles, Culex sp, Aedes dan Armigeres yang menjadi vektor filariasis di Indonesia (WHO, 1992). Menurut Noviani (2010), WHO mecatat penyakit kaki gajah di Indonesia tersebar luas hampir di seluruh propoinsi. Berdasarkan laporan dari hasil survei pada tahun 2000 yang lalu tercatat 1553 desa di 647 puskesmas tersebar di 231 Kabupaten 26 propinsi sebagai lokasi yang endemis, dengan jumlah kasus kronis 623.

Demam Berdarah Dengue (DBD) merupakan salah satu penyakit yang ditularkan oleh serangga. Beberapa tahun terakhir, kasus Demam Berdarah Dengue (DBD) seringkali muncul di musim pancaroba, khususnya bulan Januari di awal tahun seperti sekarang ini. Karena itu, masyarakat perlu mengetahui penyebab penyakit DBD, mengenali tanda dan gejalanya, sehingga mampu mencegah dan menanggulangi dengan baik. Pada tahun 2014, sampai pertengahan bulan Desember tercatat penderita DBD di 34 provinsi di Indonesia sebanyak 71.668 orang dan 641 diantaranya meninggal dunia. Angka tersebut lebih rendah dibandingkan tahun sebelumnya, yakni tahun 2013 dengan jumlah penderita sebanyak 112.511 orang dan jumlah kasus meninggal sebanyak 871 penderita. Demam berdarah dengue (DBD) merupakan penyakit yang disebabkan oleh virus Dengue yang ditularkan dari orang ke orang melalui gigitan nyamuk Aedes (Ae). Ae aegypti merupakan vektor yang paling utama, namun spesies lain seperti Ae. albopictus juga dapat menjadi vektor penular.

Nyamuk tergolong serangga yang cukup tua di alam dan telah mengalami proses evolusi serta seleksi alam yang panjang sehingga menjadikan insekta ini sangat adaptif tinggal bersama manusia (Durant, 2008). Kejadian penyakit yang penularannya dibawa oleh vektor nyamuk tersebut disebabkan oleh tingginya kepadatan vektor 
nyamuk khususnya di Indonesia (Ndione, 2007). Banyak penyakit pada hewan dan manusia dalam penularannya mutlak memerlukan peranan nyamuk sebagai vektor dari agen penyakitnya, karena perkembangan beberapa jenis nyamuk dapat membahayakan kesehatan manusia dan hewan (Vinayagam, 2008).

Pembasmian terhadap nyamuk menjadi kegiatan tidak pernah henti yang dilakukan oleh pemerintah dan mausia karena jika nyamuk dibiarkan berkembangbiak dapat menimbulkan masalah yang serius. Berbagai upaya telah dilakukan oleh pemerintah untuk mengendalikan penyakit Filariasis (Kaki Gajah) dan Demam Berdarah Dengue (DBD) yaitu Pemantauan Jentik Rutin (PJR), Pemantauan Jentik Berkala (PJB), Pemberantasan Sarang Nyamuk (PSN) melalui 3M plus (Menguras, Menutup, dan Mengubur), plus menabur larvasida, penyebaran ikan pada tem- pat penampungan air, serta kegiatankegiatan lainnya yang dapat mencegah/memberantas nyamuk Aedes berkembang biak. Pestisida alami mengandung bahan mudah dan cepat terdegradasi di alam serta mempunyai dampak yang lebih kecil terhadap lingkungan, juga karena mengandung bahan kimia (biokatif) yang toksik terhadap serangga namun mudah terurai di alam sehingga tidak mencemari linkungan yang relatif aman bagi manusia disamping itu keuntungan lain dari bahan pestisida alami, bahan ekstraknya mudah didapat dan harganya lebih ekonomis karena kedua ektrak ini merupakan limbah dari buah yang akan diolah menjadi minuman segar atau jus buah (Penghiyangani, 2010)

Tanaman Indonesia penghasil buah yang berpotensi sebagai insektisida nabati adalah alpukat (Persea americana Mill). Hasil skrining fitokimia yang dilakukan Zuhrotun (2007) menunjukan bahwa ekstrak athanol biji alpukat mengandung senyawa polifenol, tannin, flavonoid, tritertenoid, kuinon, monoterpenoid, seskuiterpenid dan saponin. Dewi (2014) menyatakan bahwa biji alpukat dapat disebut sebagai insektisida nabati (botani) karena terbukti bersifat toksik terhadap larva nyamuk Aedes aegypti $L$, granula ekstrak biji alpukat memiliki LC $_{50}$ sebesar 37,89 ppm dalam waktu 24 jam. Sirsak (Annona muricata L) seyawa lain yang bersifat larvasida adalah acetogenin, squamocin dan annonacin yang terdapat pada biji sirsak (Annona muricata L). Rosmayanti (2014) menyatakan bahan kimia acetogenin dimiliki hampir oleh seluruh famili Annonaceae, termasuk sirsak (Annona muricata L) telah banyak diketahui bahwa molekul tersebut berperan sebagai larvasida. Berdasarkan penelitian Lilipaly 
(2014) diketahui bahwa granula ekstrak biji sirsak dapat mematikan larva nyamuk Aedes aegypti $L$, dengan biji sirsak $\mathrm{LC}_{50}$ sebesar 4,331 ppm dalam waktu 24 jam.

Hal ini menjadi acuan untuk menggunakan ekstrak biji alpukat (Persea americana Mill) dan ekstrak biji sirsak (Annona muricata L) sebagai larvasida Culex sp. Larva nyamuk Culex sp dan Aedes aegypti $L$ memiliki persamaan hidup yaitu hidup pada habitat aquatik. Namun, larva Aedes aegypti L, Aedes albopictus dan Culex $s p$ quinquefasciatus berbeda habitat, morfologi dan anatomi sehingga perlu penelitian pengaruh pemberian ekstrak biji alpukat (Persea americana Mill) dan ekstrak biji sirsak (Annona muricata $L)$ terhadap mortalitas larva nyamuk Culex sp. Pengaruh larvasida terhadap larva nyamuk dapat diketahui dengan memasukan larva ke dalam suatu larutan uji (larutan larvasida) dengan berbagai konsentrasi selama 24-48 jam atau bahkan lebih (Noviani, 2010). Selama pengamatan mortalitas larva dicatat untuk mengetahui pengaruh larvasida terhadap larva nyamuk. Larva instar III yang mati menunjukan kondisi kaku dan lisis yang semakin banyak seiring meningkatnya konsentrasi ekstrak biji alpukat dan ekstrak biji sirsak.

Larva instar III merupakan larva yang sedang giat-giatnya aktif mencari makanan sebelum masa dorman yaitu instar empat saat akan menjadi pupa. Pemberian insektisida pada saat larva mencapai instar III, dengan tujuan larvasida tersebut langsung dapat terserap oleh larva bersamaan dengan pengambilan makanan sehingga akan memberih pengaruh atau efek pada sistem metabolisme larva (Connel dan Miller, 1995).

\section{MATERI DAN METODE PENELITIAN}

Penelitian ini akan dilakukan secara eksperimental di laboratorium mengunakan rancangan acak lengkap (RAL). Ekstrak biji alpukat (Persea americana Mill.) dan ekstrak biji sirsak (Annona muricata L.) masing-masing sebanyak lima perlakuan dan lima pengulangan yang diaplikasikan pada larva nyamuk Culex sp. Penelitian dilakukan di Labolatorium Biologi Dasar Prodi Biologi Kampus II Universitas PGRI Adi Buana (UNIPA) Jl. Dukuh Menanggal XII Surabaya dan Laboratorium Entomologi Tropical Diagnostic Center (TDDC) Universitas Airlangga Kampus C Jl. Mulyorejo Surabaya 60115 selama bulan Maret - Mei 2017. 
Prosedur Penelitian

Pembuatan Ekstrak Biji Alpukat (P. Americana Mill.) dan Ekstrak Biji Sirsak (A. muricata L.)

Pada pembuatan ekstrak, disiapkan biji alpukat $(P$. americana Mill.) dan biji sirsak (A. muricata $L$.) yang telah dicuci bersih dan ditiriskan. Kedua biji tersebut dikering anginkan selama 2-3 hari dan dijadikan serbuk. Serbuk biji alpukat (P. americana Mill.) dan biji sirsak (A. muricata L.) direndam dengan etanol (alcohol 96\%) selama 48-72 jam, perbandingan 100 gram serbuk dengan $1000 \mathrm{ml}$ etanol. Penyaringan filtrat rendaman biji alpukat ( $P$. americana Mill.) dan biji sirsak (A. muricata L.) menggunakan kertas saring whatmaan no. 1 berdiameter 10 . Filtrat didestilasi menggunakan alat destilator pada suhu $70^{\circ} \mathrm{C}$ selama 5 jam. Hasil destilasi diharapkan dalam keadaan cair pekat. Pengovenan cairan pekat dilakukan pada suhu $70^{\circ} \mathrm{C}$ selama 4 hari (sampai cairan berbentuk kristal/gumpalan). Serbuk biji alpukat ( $P$. americana Mill.) dan biji sirsak (A. muricata L.) diaplikasikan pada larva nyamuk Culex sp Instar III dengan konsentrasi 0 (kontrol), 2, 4, 6, dan $8 \%$.

\section{Pengamatan Larva Nyamuk} Culex sp Instar III Selama 24 Jam

Pengamatan larva pada tiap perlakuan dilakukan dengan cara memasukan larva nyamuk Culex $s p$ Instar III kedalam gelas plastic yang berisi ekstrak biji alpukat $(P$. americana Mill.) dan biji sirsak (A. muricata $L$.) dengan konsentrasi 0 , 2, 4, 6, dan 8\%, dan menghitung jumlah larva nyamuk yang mati tiap perlakuan selama 24 jam.

\section{Analisis Statistika}

Data jumlah larva nyamuk yang mati tiap perlakuan selama 24 jam dianalisis menggunakan Uji Analisis Varians (ANOVA) untuk mengetahui ada atau tidak pengaruh pemberian ekstrak biji alpukat $(P$. americana Mill.) dan biji sirsak (A. muricata L.) terhadap jumlah kematian larva nyamuk Culex $s p$ instar III antar kelompok uji. Letak perbedaan antar perlakuan diuji lanjut menggunakan uji Uji Least Significance (LSD). Kedua ekstrak biji tersebut dilakukan Analisis Probit ( $\left.\mathrm{LC}_{50}\right)$ untuk mengetahui daya bunuh ekstrak biji alpukat (Persea americana Mill.) dan biji sirsak (Annona muricata L.) terhadap larva nyamuk Culex $s p$ instar III. Analisis statistika dilakukan menggunakan perangkat lunak SPSS 16.

\section{HASIL PENELITIAN}

Mortalitas Larva Nyamuk Culex sp. yang Diberi Ekstrak Biji Alpukat (P. americana Mill)

Hasil penelitian menunjukkan bahwa pemberian ekstrak biji alpukat $(P$. americana Mill) 
berpengaruh signifikan $(\mathrm{P}<0,05)$ terhadap mortalitas larva nyamuk Culex sp. Grafik rata-rata mortalitas larva nyamuk Culex sp. yang diberi ekstrak biji alpukat $(P$. americana Mill) ditunjukkan dalam Gambar 1.

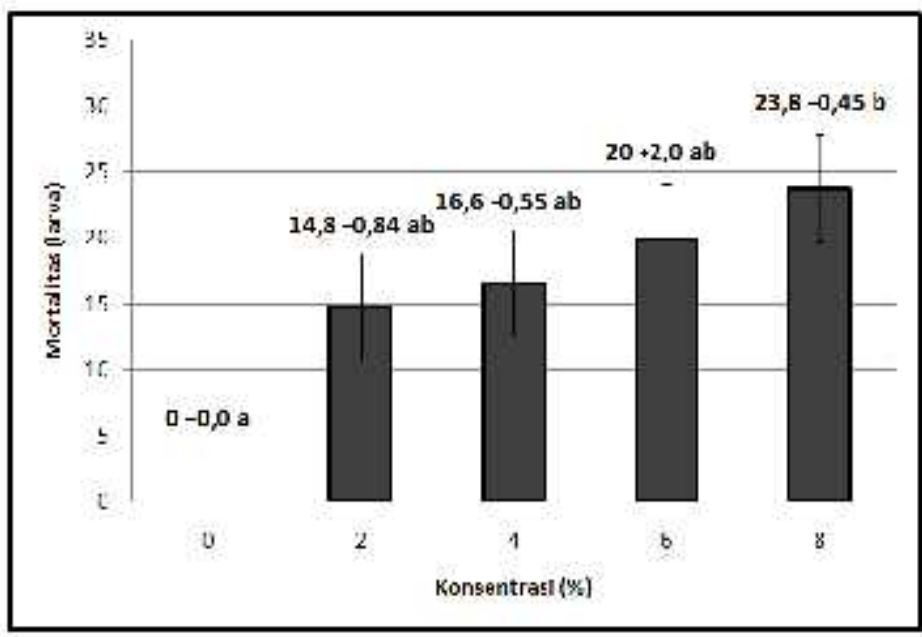

Gambar 1. Rata-rata Mortalitas Larva Nyamuk Culex sp. yang Diberi Ekstrak Biji Alpukat ( $P$. americana Mill), angka yang diberi huruf (a dan b) tidak sama menunjukkan berbeda signifikan $(\mathrm{P}<0,05)$

Pemberian ekstrak biji alpukat $(P$. americana Mill) berpengaruh signifikan $\quad(\mathrm{P}<0,05) \quad$ terhadap mortalitas larva nyamuk Culex $s p$. Mortalitas larva nyamuk Culex $s p$. yang diberi ekstrak biji alpukat $(P$. americana Mill) dengan konsentrasi 0\% (0 $\pm 0,0$ larva) berbeda signifikan $(\mathrm{P}<0,05)$ lebih rendah dibanding dengan konsentrasi $2 \%(14,8 \pm 0,84$ larva), $4 \%$ (16,6 $\pm 0,55$ larva), 6\% (20 $\pm 2,0$ larva) dan $8 \%(23,8 \pm 0,45$ larva). Selanjutnya mortalitas larva nyamuk Culex sp. yang diberi ekstrak biji alpukat ( $P$. americana Mill) dengan konsentrasi 2\% (14,8 $\pm 0,84$ larva) berbeda signifikan $(\mathrm{P}<0,05)$ lebih rendah dibanding dengan konsentrasi $4 \%(16,6 \pm 0,55$ larva), $6 \%$ (20 $\pm 2,0$ larva) dan $8 \%$
$(23,8 \pm 0,45$ larva). Kemudian mortalitas larva nyamuk Culex sp. yang diberi ekstrak biji alpukat $(P$. americana Mill) dengan konsentrasi $4 \% \quad(16,6 \pm 0,55$ larva $)$ berbeda signifikan $(\mathrm{P}<0,05)$ lebih rendah dibanding dengan konsentrasi $6 \%$ (20 $\pm 2,0$ larva) dan $8 \%(23,8 \pm 0,45$ larva). Selanjutnya mortalitas larva nyamuk Culex sp. yang diberi ekstrak biji alpukat ( $P$. americana Mill) dengan konsentrasi 6\% (20 $\pm 2,0$ larva) berbeda signifikan $(\mathrm{P}<0,05)$ lebih rendah dibanding dengan konsentrasi 8\% (23,8 $\pm 0,45$ larva). Mortalitas larva nyamuk Culex sp. yang paling tinggi terdapat pada pemberian ekstrak biji alpukat $(P$. americana Mill) dengan konsentrasi $8 \%(23,8 \pm 0,45$ larva). 
Jadi pemberian ekstrak biji alpukat ( $P$. americana Mill) dengan konsentrasi $8 \%(23,8 \pm 0,45$ larva) paling optimal dalam membunuh larva nyamuk Culex sp.

Mortalitas Larva Nyamuk Culex sp. yang Diberi Ekstrak Biji Sirsak (A. muricata L)
Hasil penelitian menunjukkan bahwa pemberian ekstrak biji sirsak (A. muricata L) berpengaruh signifikan $\quad(\mathrm{P}<0,05) \quad$ terhadap mortalitas larva nyamuk Culex $s p$. Grafik rata-rata mortalitas larva nyamuk Culex sp. yang terpapar ekstrak biji sirsak (A. muricata L) ditunjukkan dalam gambar 2 .

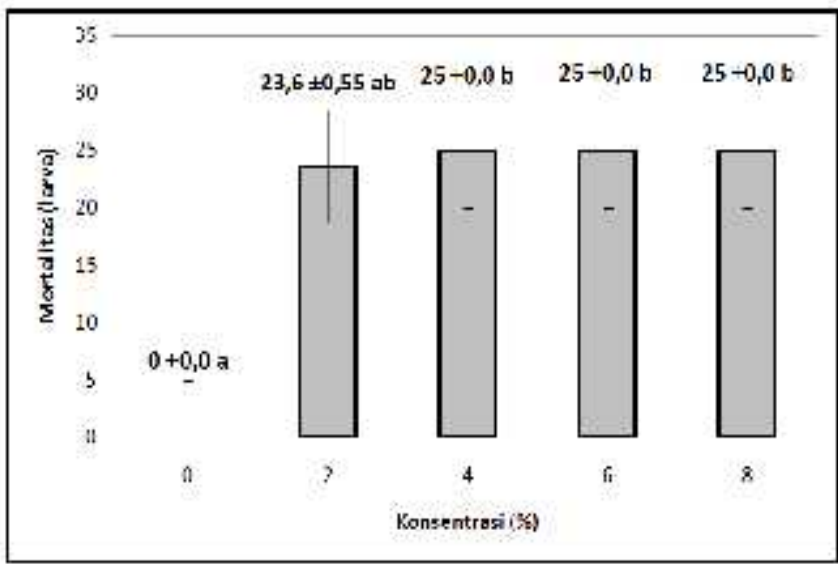

Gambar 2. Rata-rata Mortalitas Larva Nyamuk Culex sp. yang Diberi Ekstrak Biji Sirsak (A. muricata $L$ ), angka yang diberi huruf (a dan b) tidak sama menunjukkan berbeda signifikan $(\mathrm{P}<0,05)$

Pemberian ekstrak biji sirsak (A. muricata $L$ ) berpengaruh signifikan $(\mathrm{P}<0,05)$ terhadap mortalitas larva nyamuk Culex sp. Mortalitas larva nyamuk Culex $s p$. yang diberi ekstrak biji sirsak (A. muricata $L$ ) dengan konsentrasi $0 \% \quad(0 \quad \pm 0,0$ larva) berbeda signifikan $(\mathrm{P}<0,05)$ lebih rendah dibanding dengan konsentrasi $2 \%(23,6 \pm 0,55$ larva), $4 \%$ (25 $\pm 0,0$ larva), 6\% (25 $\pm 0,0$ larva) dan $8 \% \quad(25 \quad \pm 0,0$ larva).
Selanjutnya mortalitas larva nyamuk Culex $s p$. yang diberi ekstrak biji sirsak (A. muricata L) dengan konsentrasi 2\% (23,6 $\pm 0,55$ larva) berbeda signifikan $(\mathrm{P}<0,05)$ lebih rendah dibanding dengan konsentrasi 4\% (25 $\pm 0,0$ larva), 6\% (25 $\pm 0,0$ larva) dan $8 \%$ (25 $\pm 0,0$ larva). Akan tetapi mortalitas larva nyamuk Culex sp. yang diberi ekstrak biji sirsak (A. muricata $L$ ) dengan konsentrasi $4 \% \quad(25 \pm 0,0$ 
larva), $6 \%$ (25 $\pm 0,0$ larva) dan $8 \%$ (25 $\pm 0,0$ larva) tidak berbeda signifikan $(\mathrm{P}>0,05)$. Mortalitas larva nyamuk Culex $s p$. yang paling tinggi terdapat pada pemberian ekstrak biji sirsak (A. muricata L) dengan konsentrasi 4\% (25 $\pm 0,0$ larva), 6\% (25 $\pm 0,0$ larva) dan $8 \%$ (25 $\pm 0,0$ larva). Jadi pemberian ekstrak biji sirsak (A. muricata L) dengan konsentrasi $4 \% \quad(25 \quad \pm 0,0 \quad$ larva $)$ paling optimal dalam membunuh larva nyamuk Culex sp.

Perbandingan Mortalitas Larva Nyamuk Culex sp. yang Diberi Ekstrak Biji Alpukat $(P$. americana Mill) dan Ekstrak Biji Sirsak (A. muricata L)

Perbandingan mortalitas larva nyamuk Culex $s p$. pada kedua ekstrak perlakuan dapat dilihat pada Gambar 3.

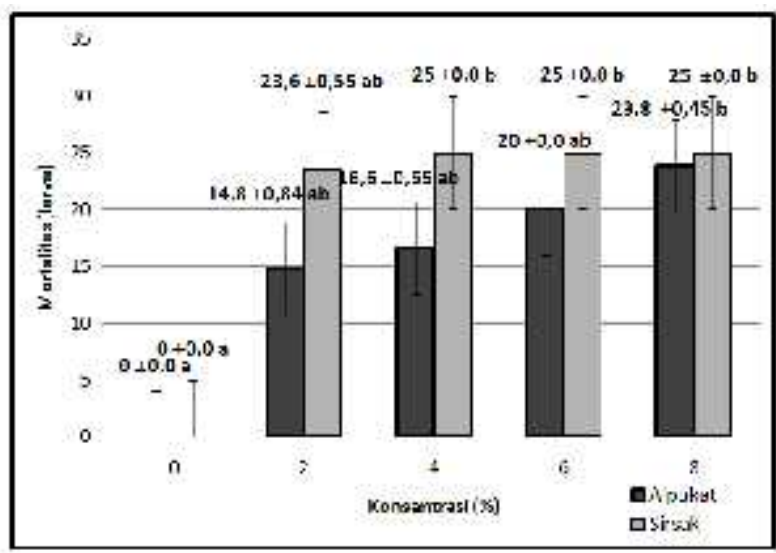

Gambar 3. Perbandingan mortalitas larva nyamuk Culex $s p$. yang diberi ekstrak biji alpukat ( $P$. americana Mill) dan ekstrak biji sirsak $(A$. muricata L)

Tabel 1.Uji T perbandingan mortalitas larva nyamuk Culex $s p$. yang diberi ekstrak biji alpukat ( $P$. americana Mill) dan ekstrak biji sirsak ( $A$. muricata L)

\begin{tabular}{lcccc}
\hline Perlakuan & $\begin{array}{c}\text { Rata- } \\
\text { Rata }\end{array}$ & $\begin{array}{c}\text { Standart } \\
\text { Deviation }\end{array}$ & $\begin{array}{c}\text { T } \\
\text { hitng }\end{array}$ & Sig \\
\hline $\begin{array}{l}\text { Ekstrak } \\
\text { Biji }\end{array}$ & 15,04 & 8,34 & & \\
Alpukat & & & - & 0,080 \\
$\begin{array}{l}\text { Ekstrak } \\
\begin{array}{l}\text { Biji Sirsak } \\
\text { Total }\end{array}\end{array}$ & 19,72 & 10,08 & 1,788 & \\
\hline
\end{tabular}


Dari tabel di atas terlihat nilai dari signifikan uji t, yaitu 0.080 $>0,05$ (5\%), ini mengartikan bahwa mortalitas larva nyamuk Culex sp. yang diberi ekstrak biji alpukat $(P$. americana Mill) dan ekstrak biji sirsak ( $A$. muricata $L$ ) tidak berbeda secara signifikan $(\mathrm{P}>0,05)$. Bisa dikatakan efektifitas ekstrak biji alpukat ( $P$. americana Mill) dan ekstrak biji sirsak (A. muricata $L$ ) tidak berbeda secara signifikan ( $>0,05)$ dalam membunuh larva nyamuk Culex sp. Akan tetapi, jika dilihat dari nilai rata-ratanya, bahwa pemberian ekstrak biji sirsak (A. muricata L) $(19,72 \pm 10,08$ larva) lebih banyak dalam membunuh larva nyamuk Culex sp. dibandingkan dengan pemberian ekstrak biji alpukat ( $P$. americana Mill $)(15,04 \pm 8,34$ larva $)$ dalam membunuh larva nyamuk Culex sp.

\section{Perbandingan Nilai Lethal Concentration $\quad \mathbf{5 0 \%} \quad$ (LC50) Ekstrak Biji Alpukat (P. americana Mill) dan Ekstrak Biji} Sirsak (A. muricata L) terhadap Mortalitas Larva Nyamuk Culex $s p$.

Analisis probit dilakukan untuk mengetahui daya bunuh atau nilai $\mathrm{LC}_{50}$ pada konsentrasi ektrak biji alpukat ( $P$. americana Mill) terhadap mortalitas larva nyamuk Culex sp. instar III yang diberi perlakuan selama 24 jam. Berdasarkan hasil analisis probit di atas dapat diketahui bahwa nilai $\mathrm{LC}_{50}$ pada konsentrasi ektrak biji alpukat ( $P$. americana Mill) sebesar $2,486 \%$ sedangkan ektrak biji sirsak (A. muricata L) sebesar $1,605 \%$ terhadap mortalitas larva nyamuk Culex sp. instar III sebanyak 50\% yang diberi perlakuan selama 24 jam.

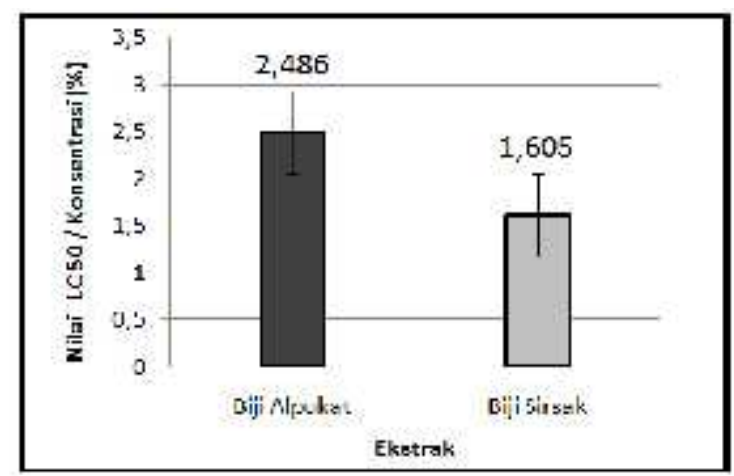

Gambar 4.Perbandingan nilai $\mathrm{LC}_{50}$ pada konsentrasi ekstrak biji alpukat ( $P$. americana Mill) dan ekstrak biji sirsak (A. muricata $L$ ) terhadap mortalitas larva nyamuk Culex sp. instar III yang diberi perlakuan selama 24 jam 
Berdasarkan

perbandingan

(Gambar

gambar

menunjukkan bahwa nilai $\mathrm{LC}_{50}$ pada ekstrak biji sirsak (A. muricata $L$ ) (konsentrasi 1,605\%) lebih optimal dibandingkan dengan nilai $\mathrm{LC}_{50}$ pada ekstrak biji alpukat $(P$. americana Mill) (konsentrasi 2,486 $\%)$ terhadap mortalitas larva nyamuk Culex sp. instar III 50\% yang diberi perlakuan selama 24 jam.

\section{PEMBAHASAN}

Mortalitas Larva Nyamuk Culex sp yang Diberi Ekstrak Biji Alpukat (P. americana Mill)

Hasil penelitian ini telah menunjukan bahwa ekstrak biji alpukat (Persea Americana mill) berpengaruh terhadap pemberian larva nyamuk Culex sp Instar III selama 24 jam yang diberi perlakuan dengan berbagai konsentrasi yaitu $0 \%$ (0 $\pm 0,0$ larva), $2 \%$ (14,8 $\pm 0,84$ larva), $4 \%$ (16,6 $\pm 0,55$ larva), $6 \%$ (20 $\pm 2,0$ larva) dan $8 \%(23,8 \pm 0,45$ larva). Mortalitas larva nyamuk Culex sp. yang paling tinggi terdapat pada pemberian ekstrak biji alpukat $(P$. americana Mill) dengan konsentrasi $8 \%$ (23,8 $\pm 0,45$ larva). Kematian larva nyamuk Culex sp. Instar III disebabkan oleh bahan aktif atau metabolit sekunder yang terkandung dalam ekstrak biji alpukat ( $P$. americana mill). Bahan aktif yang terkandung tersebut diantaranya alkaloid, saponin dan triterpenoid. Senyawa-senyawa tersebut yang terkandung dalam biji alpukat (Persea americana Mill) diduga dapat berfungsi sebagai insektisida alami (Mulyana, 2002).

Alkaloid merupakan salah satu bahan aktif yang terkandung di dalam biji alpukat (P. americana Mill) (Mulyana, 2002). Alkaloid yang masuk ke dalam tubuh larva melalui absorbsi dan mendegradasi membran sel kulit. Selain itu, alkaloid juga dapat mengganggu sistem kerja saraf larva (Dinata dalam Zuldarisma, 2013). Alkaloid merupakan anticholinesterase yang berfungsi menghambat kerja enzim asetilkolinesterase yang mempengaruhi transmisi impuls saraf. Anticholinesterase ini merupakan mekanisme kerja dari senyawa Organophospat dan Carbamat sebagai insektisida. Hal ini menyebabkan enzim cholinesterase mengalami fosforilasi dan menjadi tidak aktif. Tidak aktifnya cholinesterase menyebabkan hambatan proses degradasi acetylcholine sehingga terjadi akumulasi acetylcholine di celah sinap. Hal ini akan menyebabkan terjadi gangguan transmisi rangsang yang dapat menurunkan koordinasi otot, konvulsi, gagal nafas dan kematian (Wibawa, 2012). Selain itu, biji alpukat (P. americana Mill) juga mengandung bahan aktif, yaitu saponin. Saponin yang terkandung juga diduga sebagai insektisida alami bagi larva nyamuk Culex sp. 
Saponin merupakan zat aktif yang apabila dikocok dengan air maka akan mengeluarkan buih dan apabila dihidrolisis akan menghasilkan gula dan sapogenin. Sifat-sifat sapogenin ialah dapat menghemolisis darah, mengikat kolesterol dan toksin terhadap hewan berdarah dingin (Mulyana, 2002). Saponin merupakan glikosida triterpena dan sterol yang telah terdeteksi dalam lebih dari 90 suku tumbuhan. Saponin merupakan senyawa aktif permukaan dan bersifat seperti sabun, serta dapat dideteksi berdasarkan kemampuannya membentuk busa dan menghemolisis sel darah (Harborne, 1987). Menurut Sahsi dan Ashoke (Aminah, 2001), saponin dapat menurunkan tegangan permukaan selaput mukosa saluran pencernaan larva sehingga dinding saluran pencernaan menjadi korosif dan akhirnya rusak. Senyawa aktif saponin mempunyai efek menurunkan tegangan permukaan sehingga merusak membran sel, menginaktifkan enzim sel dan merusak protein sel. Saponin dapat berikatan dengan fosfolipid yang meyusun membran sel sehingga mengganggu permeabilitas membran sel (Widodo, 2005). Hal ini yang membuat larva nyamuk Culex sp. Selain alkaloid dan saponin, triterpenoid juga merupakan bahan aktif yang terkandung dalam biji alpukat (Persea americana Mill).

Triterpenoid dapat mempertahankan serangga dalam stadium imatur yang berlangsung lebih lama dari waktu normal sehingga tidak dapat moulting atau ganti kulit dengan sempurna, karena sebagai analog hormone juvenile. Fungsi hormone juvenille adalah menghambat proses moulting dan berakibat larva mudah mengalami trauma dari luar karena tidak terbentuknya lapisan kulit luar larva yang dapat berfungsi sebagai lapisan pelindung tubuh dari trauma. Triterpenoid berfungsi sebagai antifagus, insektisida, atau anti pemangsa dan mempengaruhi sistem saraf (Wibawa, 2012). Ketiga bahan aktif tesebut diduga yang menyebabkan larva nyamuk Culex $s p$ mengalami kematian. Hal ini diperjelas dengan penelitian mengenai biji alpukat sebagai larvasida nyamuk Aedes aegypti L. yang pernah dilakukan oleh Leite (2009) bahwa ekstrak biji alpukat memiliki kemampuan sebagai larvasida terhadap Aedes aegypti L. dengan $\mathrm{LC}_{50}$ sebesar 16,7 $\mathrm{mg} / \mathrm{L}$.

Mortalitas Larva Nyamuk Culex $s p$ yang Diberi Ekstrak Biji Sirsak (A. muricata $\mathrm{L}$ )

Hasil penelitian ini telah menunjukan bahwa ekstrak biji sirsak (Annona muricata L) berpengaruh terhadap pemberian 
larva nyamuk Culex sp Instar III selama 24 jam yang diberi perlakuan dengan berbagai konsentrasi yaitu $0 \%, 2 \%, 4 \%, 6 \%$ dan $8 \%$. Mortalitas larva nyamuk Culex sp. yang paling tinggi terdapat pada pemberian ekstrak biji sirsak ( $A$. muricata $L$ ) dengan konsentrasi $4 \%$ (25 $\pm 0,0$ larva), 6\% (25 $\pm 0,0$ larva) dan $8 \% \quad(25 \pm 0,0$ larva). Jadi pemberian ekstrak biji sirsak (A. muricata $L$ ) dengan konsentrasi $4 \%$ (25 $\pm 0,0$ larva) paling optimal dalam membunuh larva nyamuk Culex sp. Kematian larva nyamuk Culex sp. Instar III disebabkan oleh bahan aktif atau metabolit sekunder yang terkandung dalam ekstrak biji sirsak (A. muricata L). Bahan aktif yang terkandung tersebut diantaranya asetogenin, squamocin, dan annonacin. Senyawa-senyawa tersebut yang terkandung dalam biji sirsak (A. muricata L) diduga dapat berfungsi sebagai insektisida alami (Mulyana, 2002).

Acetogenin

senyawa polyketides dengan struktur 30-32 rantai karbon yang tidak bercabang yang terikat pada gugus 5-methyl-furanone. Pada konsentrasi tinggi, senyawa acetogenin memiliki keistimewaan sebagai anti feedent . Dalam hal ini, racun membunuh serangga dengan mengintervensi proses metabolismenya dan mengganggu respirasi sel dan bekerja di mitokondria, sehingga larva nyamuk Culex sp tidak lagi bergairah, karena bersifat racun perut yang bisa mengakibatkan larva nyamuk Culex sp akan mati (Septerina, 2002). Selain itu, biji sirsak (A. muricata L) juga mengandung squamocin.

Menurut Mitsui et al. (1991) bahwa squamocin mampu menghambat transport electron pada sistem respirasi sel, sehingga menyebabkan gradien proton terhambat dan cadangan energi tidak dapat membentuk ATP. Biji sirsak (Annona muricata L) juga mengandung annonacin yang berfungsi sebagai insektisida alami.

Annonacin merupakan senyawa yang tergolong mempunyai sifat toksisitas yang cukup efektif terhadap serangga dan ordo Diptera bersifat sitoksik dan neuroksik. Racun fidik ini dapat membunuh larava nyamuk Culex sp dengan cara menutupi lubang-lubang pernapasan sehingga larva nyamuk dapat mati lemas karena kekurangan oksigen (Mitsui et al., 1991).

\section{KESIMPULAN}

Pemberian ekstrak biji alpukat (P. americana Mill) dan ekstrak biji sirsak (A. muricata $L$ ) berpengaruh terhadap mortalitas larva nyamuk Culex sp. Pemberian konsentrasi 8\% ekstrak biji alpukat (P. americana Mill) optimal dalam membunuh larva nyamuk Culex sp. sedangkan ekstrak biji sirsak (A. muricata $L$ ) optimal pada konsentrasi $4 \%$ dalam membunuh larva nyamuk Culex sp. Ekstrak biji alpukat (P. americana 
Mill) memiliki efek sebagai larvasida terhadap nyamuk Culex sp. instar III dengan nilai LC $_{50}$ pada konsentrasi 2,486\% sedangkan pada ekstrak biji sirsak (A. muricata $L$ ) dengan nilai $\mathrm{LC}_{50}$ pada konsentrasi $1,605 \%$.

\section{DAFTAR PUSTAKA}

Aminah, N.S. Singgih H. \& Soetiyono P. 2001. S. rarak, $D$. metel dan E. prostata sebagai Larvasida Aedes aegypti. Jurnal Cermin Dunia Kedokteran, 131.

Azari-Hamidian, 2007, Larval Habitat Characteristics of Mosquitoes of the Genus Culex (Diptera: Culicidae) in Guilan Province, Iranian Journal of Arthropod-Borne Diseases, 1 (1), 9-20.

Connel, W.,DES.,\& Miller, J.G., 1995. Kimia dan Ekotoksikologi Pencemaran. Universitas Indonesia, Jakarta.

Ditjen POM. 2000. Parameter Standar Umum Ekstrak Tumbuhan Obat, Departemen Kesehatan RI. Jakarta. Halaman. 1, 10-12.

Durant, Sarah E. 2008. Amphibian predation on larval mosquitoes. Elsavier Saunders, 2005: 270-5.

Hairani, S. (2014). Efektivitas Ekstrak Daun Mudu (Garcinia dulcis) Sebagai Larvasida Nyamuk Culex sp dan Aedes aegypti. Skripsi. Sarjana
Kedokteran Hewan Bogor: Institut Pertanian Bogor.

Harborne, J.B. 1987. Metode Fitokimia, Penuntun Cara Modern Menganalisis Tumbuhan. Terjemahan oleh K. Padmawinata dan I. Soediro. Bandung: Institut Teknologi Bandung

Islamiarto. 2012. "Uji Efektifitas Pasta Biji Sirsak (Annona muricata Linn) Dalam

Menekan Gall dan Populasi Nematoda (Meloidogyne spp) pada Tanaman Tomat (Lycopersicum esculentium Mill.)". Tidak Diterbitkan. Skripsi. Bandung: Fakultas Pertanian Universitas Padjadjaran

Leite, J.J.G. 2009. Chemical Composition, Toxicity and Larvacidal and Antifungal Activities of Persea americana (Avocado) Seed Extract. Revista da Brasileira de Mediciana Tropical. Vol. 42 (2): 110-113

Lilipaly, N.L.Y. 2014. “Toksisitas Granula Ekstrak Biji Sirsak (Annona muricata L.) Terhadap Larva Nyamuk Aedes aegypti L.". Tidak Diterbitkan. Skripsi. Jember: Universitas Jember

Mitsui, T., S. Atsusawa., K. Ohsawa., I. Yamamoto., T. Miyake And T. Umehara. 1991. Search for insect growth regulators In Pesticides and 
the future: Toxicological Studies of Risks and Benefits. Rev. Pestic. Toxicol. I. North Carolina State University. Raleigh. North Carolina.

Mulyana. 2002. Ekstraksi Senyawa Aktif Alkaloid, Kuinon, dan Saponin dari Tumbuhan Kecubung seavagai Larvasida dan Insektisida Terhadap Nyamuk Aedes aegypti. Bogor: Jurusan Kimia IPB

Ndione RD, Faye O, Ndiaye M, Dieye A., and Afoutou JM. 2007. Toxic effects of neem products (Azadirachta indica A. Juss) on Aedes aegypti Linnaeus 1762 larvae.

Noviani, B. 2010. Yogyakarta : Jurusan Biologi, Fakultas Teknologi, Universitas Atma Jaya Yogyakarta.

Pahlevi RI, Santoso. Penentuan Vector Filariasis dan Spesies Mikrofilaria di Puskesmas Batumarta VII Kab. OKU Timur Tahun 2012 . Jurnal Pembangunan Manusia. 2013 Panghiyangani, R., Isnaini \& Dodo T. 2010. Aktivitas Larvisida Minyak Atsiri Rimpang Kunyit Putih (Curcuma zedoaria) terhadap Larva Aedes aegypti. Majalah Kedokteran FK UKI. Vol. 27 (3)

Rosmayanti, K. 2014. "Uji Efektivitas Ekstrak Biji Sirsak (Annona muricata L.) Sebagai Larvasida Pada Larva Aedes aegypti Instar III/IV'. Tidak Diterbitkan. Skripsi. Jakarta: Universitas Islam Negeri Syarif Hidayatullah

Rukmana, R. 1997. Budi Daya Alpukat. Yogyakarta: Kanisius

Septerina. 2002. Pengaruh Ekstrak Daun Sirsak sebagai Insektisida Rasional terhadap Pertumbuhan dan Hasil Tanaman Paprika Varietas Bell Boy. Tesis S-2 Fakultas Pertanian. Universitas

Muhammadiah. Malang.

Soedarto, 1992. Entomologi Kedokteran. Cetakan I. EGC, Jakarta.

Soedarto. 2008. Parasitologi Klinik. Airlangga University Press. Surabaya

Vinayagam, A. 2008. Larvicidal Activity of Some Medicinal Plant Extracts Against Malaria Vector Anopheles stephensi

Wibawa, R.R. 2012. "Potensi Ekstrak Biji Mahkota Dewa (Phaleria macrocarpa)

Sebagai Insektisida Terhadap Nyamuk Aedes aegypti Dengan Metode Semprot". Tidak Diterbitkan. Skripsi. Jember: Universitas Jember

World Health Organization. Lymphatic Filariasis. The disease and its control. Technical report series. Geneva: WHO; 1992. 
Zuldarisman, M., Ishak H. \& Anwar. 2013. Efektivitas Air Perasan Buah Belimbing Wuluh (Averrhoa bilimbi L) Terhadap Kematian Larva Aedes aegypti Dan Larva Anopheles subpictus. Makassar: Bagian Kesehatan Lingkungan Fakultas Kesehatan Masyarakat Universitas Hasanuddin 